EWA MATCZUK* - LUBLIN

\title{
POLSKIE CZASOPISMA ELEKTRONICZNE ON-LINE Z DZIEDZINY BIBLIOTEKOZNAWSTWA
}

Rosnące w ostatnich latach zapotrzebowanie na szybką informację przyśpieszyło zainteresowanie dostępem do czasopism publikowanych $\mathrm{w}$ formie elektronicznej. Rozwój technologii, dostępność komputerów osobistych oraz rozwój formatów danych dla pełnych tekstów publikacji w znacznym stopniu przyczyniły się do sukcesów czasopism elektronicznych.

W miarę rozwoju zasobów informacyjnych oraz ze względu na różnorodność umieszczanych w sieci publikacji pojawiać się zaczęły próby klasyfikacji tego typu wydawnictw. Środowisko elektroniczne umożliwia ciąłe dokonywanie zmian, aktualizację umieszczonych w nim dokumentów. Termin czasopisma internetowe (elektroniczne) zarezerwowany jest dla dokumentów elektronicznych charakteryzujących się cechami właściwymi dla czasopism tradycyjnych, tj. periodycznością ukazywania się, skończonych pod względem redakcyjnym kolejnych numerów pisma ${ }^{1}$. Cechami wyróżniającymi czasopismo elektroniczne są forma dostępu oraz charakterystyczny format danych zapisu².

Obecnie stosuje się kilka kryteriów podziału tych wydawnictw. W artykule tym uwzględniam tylko jedno kryterium: formę ukazywania się. Według niego czasopisma elektroniczne można podzielić na dwie grupy: czasopisma sensu stricte cyfrowe i posiadające swoje odpowiedniki w formie drukowanej.

Pierwsze próby tworzenia wydawnictw elektronicznych sięgają lat 40-tych $\mathrm{XX}$ w. W następnych okresach podejmowano kolejne próby tworzenia i udostępniania czasopism elektronicznych. W drugiej połowie lat 80-tych następuje wyraźna ich popularyzacja ${ }^{3}$. W drugiej połowie lat 90-tych rozwój czasopism elektronicznych zdominowało powstanie światowej sieci WWW. Wydawcy czasopism

* Ewa Matczuk - mgr bibliotekoznawstwa i informacji naukowej, pracownik Oddziału Komputeryzacji BG UMCS.

${ }^{1}$ M. Stepowicz, Cechy formalne czasopism internetowych, Warszawa 2000, s. 6.

${ }^{2}$ K. Klanowska, Czasopisma elektroniczne „Poradnik Bibliotekarza”, 10 (2002) s. 6.

${ }^{3}$ P. Nowak, Wybrane problemy efektywności polskich czasopism naukowych z dziedziny humanistyki, Poznań 2000, s. 29. 
tradycyjnych zaczęli równoległe wydawanie wersji elektronicznych i drukowanych periodyków oraz podjęli współpracę z komercyjnymi dostawcami danych ${ }^{4}$.

W Polsce pierwsze czasopismo elektroniczne w sieci powstało na początku lat 90-tych (Donosy). Zaraz po nim zaczęły się pojawiać elektroniczne wersje czasopism drukowanych. Natomiast pierwsze elektroniczne czasopismo bibliotekarskie on-line pojawiło się w 1997 r. i było kontynuacją wersji drukowanej Biuletynu Informacyjnego $B G A E w$ Krakowie, dwa lata później pojawił się $E B I B$ - pierwsze $\mathrm{z}$ założenia czasopismo tylko elektroniczne.

Oferta czasopism z zakresu bibliotekoznawstwa od dłuższego czasu jest stabilna pod względem liczby i wynosi 58 tytułów $^{5}$ (niektóre tytuły przestały się ukazywać, przybyły nowe). Natomiast kondycja tych czasopism jest raczej słaba $\mathrm{w}$ porównaniu z periodykami z innych dziedzin.

Próby poszukiwania w Internecie polskich czasopism z zakresu bibliotekoznawstwa nie jest łatwe. Trudno znaleźć stronę, która zawierałaby wyczerpująca ich listę. Serwis EBIB też nie gwarantuje otrzymania kompletu informacji, gdyż zawiera tylko wykaz 16 tytułów, (w tym 1 nieukazujący się, 1 zawieszony; 9 zawierających spisy treści, w tym 2 czasopisma ukazujące się wyłącznie on-line oraz 1 posiadający mutację w wersji elektronicznej).

Niestety w praktyce polskie cyfrowe czasopisma bibliotekarskie nie odgrywają poważniejszej roli; elektronicznych czasopism pełnotekstowych jest zaledwie 5. Natomiast czasopism posiadających wersje równoległe - 13, tytułów umieszczających swoje spisy treści na stronach WWW - 23, ukazujących się wyłącznie w wersji drukowanej 17. Spośród tytułów ukazujących się on-line tylko Rocznik Biblioteki Narodowej jest czasopismem naukowym, ale ukazuje się w 2 wersjach: drukowanej i on-line.

Tematykę czasopism pełnotekstowych, które ukazują się obecnie, można ogólnie podsumować: obok debat ogólnopolskich z zakresu szeroko pojętego bibliotekoznawstwa poruszane są tematy lokalne oraz dotyczące różnych grup bibliotekarzy, np. bibliotekarzy-nauczycieli. W czasopismach tych też są zawarte informacje pochodzące z innych dyscyplin (zwłaszcza w EBIB).

Obecnie coraz bardziej wzrasta zainteresowanie najnowszymi źródłami informacji. Bibliotekarze zaczynaja preferować te formy przekazywania informacji i coraz częściej wykorzystują je. Dlaczego więc czasopisma o zasięgu ogólnopolskim, charakterze naukowym, wydawane przez ośrodki akademickie umieszczaja tylko spisy treści na stronach WWW i są wydawane tylko w wersji drukowanej? Jakie są przyczyny tak niskiego stopnia elektronizacji prasy bibliotekarskiej? Czy na przeszkodzie stoją bariery techniczne, czy bariery mentalne potencjalnych twórców i odbiorców czasopism elektronicznych? Ocena tego faktu nie jest prosta. Na pewno nie przyniesie jednoznacznych odpowiedzi.

$\mathrm{Na}$ świecie od kilkunastu lat można zaobserwować m.in. następujące tendencje: wzrost liczby czasopism w postaci tradycyjnej i elektronicznej, wzrost cen czasopism, w bibliotekach naukowych zauważalna jest migracja od tradycyjnych

${ }^{4}$ M. Nahotko, M. Nahotko, Powstanie i rozwój czasopism elektronicznych, w: Przestrzeń informacji i komunikacji, red M. Kocójowa,. Kraków 2004..

${ }^{5}$ Dane uzyskane z przeprowadzonego przez autorkę sondażu. 
drukowanych zbiorów do form elektronicznych, maleją środki finansowe przeznaczone za zakup literatury $\mathrm{w}$ bibliotekach naukowych, powstają nowe modele finansowania czasopism elektronicznych. Pojawiają się coraz to nowe inicjatywy na świecie i w Polsce, które mają na celu wolny i bezpłatny dostęp do informacji 6 .

Zwiększające się znaczenie czasopism elektronicznych oraz coraz większy ich odbiór społeczny znalazły też odbicie w czasopismach $\mathrm{z}$ dziedziny bibliotekarstwa. Bibliotekarze, szukając odpowiedzi na trudne problemy w czasopismach fachowych, czekają na szybką informację. Odpowiedzią na takie oczekiwania mogą być pojawiające się nieśmiało czasopisma bibliotekarskie $\mathrm{w}$ wersji elektronicznej. Co prawda nie zostaliśmy zasypani lawina nowo powstających czasopism elektronicznych, ale pojawiły się cyfrowe kontynuacje tytułów już istniejących.

W wersji pełnotekstowej ukazują się wyłącznie w sieci (w nawiasach rok rozpoczęcia wydawania on-line) następujące czasopisma: Biuletyn Informacyjny $B G$ AE w Krakowie (1997), EBIB (1999), Bibliotekarz Warmińsko-Mazurski (2003), Warsztaty Bibliotekarskie (2004), e-Kurier NB (2005).

Krótka charakterystyka powyższych tytułów w kolejności alfabetycznej:

Bibliotekarz Warmińsko-Mazurski ${ }^{7}$ (ISSN 1426-4218) - czasopismo o charakterze regionalnym. Jest kontynuacją kwartalnika Bibliotekarz Olsztyński wydawanego od 1983 r. przez Wojewódzką Bibliotekę Publiczną im. Emilii Sukertowej-Biedrawiny w Olsztynie. Od 1992 r. pismo, mimo że jest kwartalnikiem, praktycznie ukazuje się w cyklu półrocznym- wydawane są numery łączone $1 / 2$ i 3/4. W 1999 r. nastappiła zmiana tytułu na Bibliotekarz Warmińsko-Mazurski i czasopismo otrzymało równoległą do drukowanej wersję internetową. Od nr 1/2 2003 r. tytuł ukazuje się wyłącznie w formie elektronicznej.

W 1988 r. Bibliotekarz Olsztyński zmienił szatę graficzną i wprowadził układ działów obowiązujący do dziś (także w czasopiśmie elektronicznym). Materiały grupowane są w cyklach: O naszych bibliotekach, Ludzie z kręgu ksiażki, Warto wiedzieć, Pomoce metodyczne, Zestawienia bibliograficzne, Nowości wydawnicze, Kalendarium rocznic, Kalendarium wydarzeń z życia bibliotek publicznych. Zawiera: materiały, artykuły instrukcyjno-metodyczne oraz bibliografię o tematyce regionalnej. Oprócz informacji, pomocy metodycznych jest w nim miejsce na wymianę doświadczeń, zamieszczane są analizy roczne działalności bibliotek w województwie; są prezentowane biblioteki z regionu, sylwetki literackie księgarzy, historyków, bibliotekarzy, wydawców związanych z regionem. Część materiałów ma charakter dokumentacyjny (wyniki konkursów). Z założenia odbiorcami periodyku są bibliotekarze z bibliotek publicznych województwa.

Wydawnictwo finansuje Biblioteka. Selekcje merytoryczną prowadzi redakcja, artykuły nie są recenzowane. Publikują zarówno bibliotekarze z tej biblioteki,

${ }^{6}$ Open Access, Open Access Initative; w Polsce: ePolska, Program rozwoju i utrzymania infrastruktury informacyjnej i informatycznej nauki oraz jej zasobów w postaci cyfrowej na lata 20062009 - 28.12.2005 [dostęp 05.10.06]. Dostępny w Internecie: http://www.mnisw.gov.pl/mein/index. jsp?place $=$ Menu08\&news_cat_id $=732 \&$ layout $=2$

${ }^{7} \mathrm{http}: / /$ www.wbp.olsztyn.pl/bwm/ [dostęp 18.07.07]. 
jak i osoby z zewnątrz. W skład zespołu redakcyjnego wchodzą olsztyńscy bibliotekarze. Drukowane numery archiwalne są dostępne w bibliotece, a także można pobrać dany numer czasopisma $\mathrm{w}$ formacie zip.

Biuletyn Informacyjny BG AE w Krakowie ${ }^{8}$ (ISSN 1640-0542) jest kontynuacją drukowanego Biuletynu Informacyjnego wydawanego w latach 1993-1997 przez Bibliotekę Główną Akademii Ekonomicznej w Krakowie. Ukazuje się nieregularnie. Od nr 12/1997 r. zaczął się ukazywać on-line. Jest to periodyk o zasięgu lokalnym. Zespół redaktorski selekcjonuje materiały, także je zamawia, kierując się tym, co się dzieje w środowisku ważnego bądź interesującego. Autorami tekstów są wyłącznie pracownicy biblioteki. Archiwizacja jest na dysku komputera.

Biuletyn zawiera artykuły informacyjne, komunikaty o nabytkach Biblioteki (stałe rubryki nowości), sprawozdania z konferencji, z prac Rady Bibliotecznej oraz ciekawostki. Obecnie stałymi rubrykami są: Konferencje (streszczenie, komunikaty z odbytych konferencji), Nowości (nowe nabytki biblioteki oraz nowe publikacje w zbiorach Centrum Dokumentacji Europejskiej, Biblioteki Depozytowej Banku Światowego, Biblioteki Depozytowej EBOR i Biblioteki Depozytowej IMF), Wystawy w Bibliotece, Sprawozdania z zebrań Rady Bibliotecznej, Z historii ruchu wydawniczego w Polsce, Czy wiesz, że... (krótkie notatki zawierające aktualności dotyczące biblioteki), Wyciagnięte z sieci (nowinki z zakresu bibliotekoznawstwa, np. nowa baza, linki do baz, biblioteki cyfrowe). Biuletyn nie jest dodatkowo finansowany, wszelkie prace $\mathrm{z}$ nim związane są prowadzone w ramach obowiązków zawodowych.

$\boldsymbol{E B I B}^{9}$ (ISSN 1507-7187) ukazuje się od 1999 r. z częstotliwością 10 numerów na rok. Wydawca jest Komisja Wydawnictw Elektronicznych Stowarzyszenia Bibliotekarzy Polskich. Jest to czasopismo o zasięgu ogólnopolskim. Czasopismo zawiera plan numerów na cały rok. Redaktorem każdego numeru jest inna osoba, każdy numer ma temat przewodni i zawarte w nim artykuły bezpośrednio tego tematu dotyczą. Poruszane są aktualne problemy bibliotekarstwa z nastawieniem na opisywanie tendencji rozwoju bibliotek na świecie. Od 2000 r. EBIB posiada także angielską wersję abstraktową. Wcześniej czasopismo było recenzowane, ale ze względu na przedłużający się czas wydawniczy, zrezygnowano z tego. Artykuły są oceniane przez Kolegium Redakcyjne. Redaktorzy są rozsiani po całej Polsce, komunikują się poprzez pocztę elektroniczna.

Publikowanie w $E B I B$ wiąże się $\mathrm{z}$ dobrowolnym nieodpłatnym udostępnianiem tekstu. W biuletynie promowane są: nowoczesne zarządzanie biblioteką i jakością, technologie informacyjne, biblioteki cyfrowe, fachowa obsługa klientów bibliotek, permanentne kształcenie kadr, otwarta komunikacja społeczna, marketing usług, profesjonalna informacja, społeczeństwo informacyjne, projekty Unii Europejskiej, standardy światowe i inne sprawy, które są obecne we współczesnym światowym bibliotekarstwie.

\footnotetext{
${ }^{8}$ http://kangur.ae.krakow.pl/Biblioteka/Biuletyn/index.php [dostęp 18.07.07].

${ }^{9} \mathrm{http}: / /$ ebib.info/biuletyn/ [dostęp 18.07.07].
} 
Do 2000 r. włącznie serwisy towarzyszyły biuletynowi, a od 2001 r. istnieje serwis Elektroniczna Biblioteka, który obejmuje 3 równorzędne części: biuletyn, serwisy informacyjne i usługi. $E B I B$ daje możliwość przeszukiwania zawartości publikacji. $E B I B$ utrzymuje się dzięki reklamom zamieszczanych na stronie serwisu oraz dzięki sponsorom.

Od stycznia $2001 \mathrm{r}$. czasopismo weszło w struktury SBP, ze względu na osobowość prawną Stowarzyszenia dało to możliwość pozyskiwania i wydawania pieniędzy.

e-Kurier NB: magazyn internetowy nauczycieli bibliotekarzy, członków Towarzystwa Nauczycieli Bibliotekarzy Szkót Polskich oraz innych organizacji bibliotekarskich, bibliotekarzy bibliotek pedagogicznych, publicznych, naukowych i kościelnych oraz czytelników ${ }^{10}$ ukazuje się od 30 sierpnia 2005 r. w cyklu miesięcznym, czasem $2-4$ mutacje w miesiącu. Wydawcą jest Jurajski Oddział Towarzystwa Nauczycieli Bibliotekarzy Szkół Polskich w Częstochowie. e-Kurier jest udostępniany na platformie cyfrowej ENSIL. Jest to czasopismo o charakterze informacyjnym. Publikowane są artykuły głównie dotyczące działalności Towarzystwa, dotyczące bibliotek szkolnych oraz informacje przekazywane przez członków TNBSP. Miesięcznik przedstawia także bieżące informacje ważne dla bibliotekarzy. Pismo pełni rolę łącznika oraz dostarczyciela informacji dla członków TNSBP. W założeniu pismo jest skierowane do szerokiego grona odbiorców. Tytuł nie posiada stałych rubryk.

Warsztaty Bibliotekarskie ${ }^{11}$ (ISSN 1643-0719) to jedyne tego typu czasopismo fachowe o charakterze informacyjno-metodycznym wydawane przez bibliotekę pedagogiczną.

Warsztaty Bibliotekarskie ukazują się od 2002 r., wydawane są przez Bibliotekę Pedagogiczną w Piotrkowie Trybunalskim jako kwartalnik. Pismo przez dwa lata ukazywało się nieodpłatnie w wersji drukowanej na terenie powiatu piotrkowskiego, docierając do bibliotek szkolnych. Od 2004 r. ukazuje się wyłącznie $\mathrm{w}$ formie elektronicznej i jest ogólnodostępne. W związku z tym zmienił się profil odbiorcy- korzystają z niego nauczyciele i bibliotekarze z całej Polski. Tytuł ma następujące działy: $Z$ teorii, Rozwój zawodowy, Warsztat nauczyciela i bibliotekarza, Edukacja Ekologiczna, Z doświadczeń, Eko-link.

Porusza problemy związane z pracą zawodową, edukacją czytelniczo-medialną, regionalną oraz artykuły propagujące treści związane z ekologią i ochroną środowiska. Służy do przekazywania informacji oraz nawiązaniu współpracy ze środowiskiem bibliotekarzy szkolnych. Przede wszystkim są to prace dotyczące teorii i praktyki bibliotekarstwa. Wiele opublikowanych prac związanych jestz międzyprzedmiotowymi ścieżkami edukacyjnymi, ze szczególnym uwzględnieniem edukacji czytelniczej i medialnej, ekologicznej oraz prozdrowotnej. Obok rozpraw teoretycznych można znaleźć scenariusze zajęć, konspekty lekcji, programy edukacyjne i wychowawcze, projekty czy wskazówki dotyczące rozwoju zawo-

\footnotetext{
${ }^{10} \mathrm{http}: / /$ www.actual2005.republika.pl/ [dostęp 18.07.07].

${ }^{11} \mathrm{http}: / /$ www.pedagogiczna.edu.pl/warsztat/index.htm [dostęp 18.07.07].
} 
dowego. Warsztaty są kierowane do nauczycieli bibliotekarzy szkolnych wszystkich szkół różnych szczebli z całej Polski.

Autorami sa pracownicy Biblioteki oraz bibliotekarze innych bibliotek pedagogicznych, szkolnych, publicznych i naukowych z całej Polski oraz pozostali pracownicy oświaty. Kolegium Redakcyjne ocenia i przeprowadza selekcję nadesłanych artykułów.

Warsztaty Bibliotekarskie są finansowane przez Bibliotekę Pedagogiczną w Piotrkowie Trybunalskim. Wersja drukowana była dofinansowywana w 50\% przez Wojewódzki Fundusz Ochrony Środowiska i Gospodarki Wodnej w Łodzi ze względu na treści ekologiczne pisma. Czasopismo jest archiwizowane na płytach CD oraz na serwerze.

Spośród omówionych 5 tytułów żaden nie jest pismem recenzowanym. Publikowane materiały są oryginalne, nie wydawane w innej formie (drukowanej). Oprócz e-Kuriera $N B$ wszystkie artykuły mają wymienionych autorów publikacji. W EBIB-ie pod każdym artykułem jest szczegółowy opis bibliograficzny, w Biuletynie Informacyjnym Biblioteki Głównej Akademii Ekonomicznej w Krakowie jest oznaczenie numeru i rok. W większości tytułów istnieje możliwość przeglądania spisów treści. Tylko EBIB i Biuletyn Informacyjny Biblioteki Głównej Akademii Ekonomicznej w Krakowie posiadają możliwość przeszukiwania zawartości publikacji.

Wyżej wymienione czasopisma są udostępniane czytelnikom bezpłatnie na stronach WWW. Trzy tytuły korzystają z darmowych oprogramowań dostępnych na polskim rynku: Joomla! (EBIB) czy Republika (e-Kurier NB, Warsztaty Bibliotekarskie). Natomiast składem wersji elektronicznej Bibliotekarza WarmińskoMazurskiego zajmuje się komercyjna firma. Tylko Biuletyn Informacyjny Biblioteki Gtównej Akademii Ekonomicznej w Krakowie jest dostępny w ramach serwisu tej Biblioteki.

Wśród czasopism elektronicznych z zakresu bibliotekoznawstwa, przeważają wydawnictwa będące mutacjami czasopism drukowanych. Publikują artykuły ukazujące się równolegle w innej formie (drukowanej) oraz zamieszczają artykuły w wyborze.

Poniżej krótka charakterystyka tych tytułów wymienionych alfabetycznie:

Biblioteka $^{12}$ (ISSN 1506-3615) - rocznik wydawany od 1997 r. przez Uniwersytet im. A. Mickiewicza w Poznaniu, pomyślany został jako kontynuacja czasopisma wydawanego pod tym samym tytułem w latach 1960-1970, redagowanego przez pracowników Biblioteki UAM i wychodzącego w serii Prace naukowe Uniwersytetu im. Adama Mickiewicza (ISSN 0551-6579). Dla zachowania ciagłości, nowy i różniący się od poprzednika zarówno formą, jak i rozszerzonymi założeniami programowymi rocznik otrzymał podwójną numerację. Pełny dostęp do artykułów w formacie djvu za lata 1997-2001 możliwy jest przez Wielkopolską Bibliotekę Cyfrową. Tytuł ma zasięg regionalny.

${ }^{12}$ http://lib.amu.edu.pl/publikacje/bu.php lub http://www.ebib.info/serwisy/czsp/polskie/ [dostęp 18.07.07]. 
Bibliotheca Nostra: biuletyn informacyjny ${ }^{13}$ (ISSN 1734-6576) - kwartalnik wydawany od 2005 r. przez Bibliotekę Główną AWF w Katowicach w obu wersjach równolegle. Pełny dostęp do artykułów możliwy jest przez format pdf od pierwszego numeru do bieżącego. Czasopismo zawiera sprawozdania z konferencji, recenzje książek, rozważania na temat wpływu techniki na dostęp do wiedzy, funkcjonowanie biblioteki, artykuły dotyczące biblioteki AWF, statystyki. Czasopismo ma zasięg regionalny.

Bibliotekarz Lubelski ${ }^{14}$ (ISSN 0137-9895) - rocznik (do 1985 r. kwartalnik) wydawany przez Wojewódzką Bibliotekę Publiczną im. H. Łopacińskiego w Lublinie. Na stronie WWW dostępne są pełne teksty w formacie pdf za lata 20012005. Rocznik zawiera: materiały związane $\mathrm{z}$ działalnością bibliotek dotyczące historii bibliotek i kultury regionu, analizy czytelnictwa, życiorysy zasłużonych bibliotekarzy oraz stałą rubrykę: przegląd wydawnictw o regionie. Tytuł ma charakter regionalny.

Bibliotekarz Plocki ${ }^{15}$ (ISSN 1234-1215) - kwartalnik wydawany od $1995 \mathrm{r}$. przez Książnicę Płocką im. W. Broniewskiego w Płocku. Artykuły są dostępne w wyborze w formacie html, doc oraz pdf od $\mathrm{nr} 2 / 2003$ do numeru bieżącego. Zawiera materiały ze sprawozdań z działalności Książnicy, informacje o bibliotekach publicznych, kronikę ważniejszych wydarzeń kulturalnych. Czasopismo ma zasięg regionalny.

Bibliotekarz Podlaski ${ }^{16}$ (ISSN 1640-7806) - półrocznik wydawany od 2000 r. przez Książnicę Podlaską w Białymstoku przy współpracy Miejskiej biblioteki Publicznej w Łomży i Biblioteki Publicznej w Suwałkach. Na stronach WWW możliwy jest pełny dostęp w formacie pdf od $\mathrm{nr} 1 / 2000 \mathrm{r}$. do numeru bieżącego. Artykuły dotyczą problematyki historycznej, bibliotek i czytelnictwa Podlasia. Półrocznik jest czasopismem regionalnym.

Biuletyn Informacyjny ${ }^{17}$ - kwartalnik jest wydawany od 1995 r. (od 1999 r. również w formie elektronicznej) przez Bibliotekę Główną AWF w Krakowie. Pełny dostęp do tekstów artykułów jest w formacie html od $1999 \mathrm{r}$. od $\mathrm{nr} 4$ do 2001 r. nr 3, w formacie pdf od $\mathrm{nr}$ 4/2001 r. Artykuły dotyczą zagadnień związanych z działalnością bibliologiczno-informatyczną biblioteki, historii bibliotek, książki oraz spraw bieżących. Tytuł o zasięgu regionalnym.

Biuletyn Informacyjny Biblioteki Narodowej ${ }^{18}$ (ISSN 0006-3983) - kwartalnik jest wydawany od 1958 r. (od 2000 r. w wersji elektronicznej) przez Bibliotekę Narodową. Artykuły są dostępne ze spisami treści w formacie pdf od nr 3/2000 r. do numeru bieżącego. Zawiera informacje o bieżących problemach Biblioteki Narodowej, prowadzonych przez bibliotekę pracach, wydarzeniach kulturalnych

${ }^{13} \mathrm{http} / / /$ www.biblioteka.awf.katowice.pl/biuletyn.html [dostęp 18.07.07].

${ }^{14} \mathrm{http}$ ://hieronim.wbp.lublin.pl/wbp/b/publ/publ_bibliotekarz.htm [dostęp 18.07.07].

${ }^{15} \mathrm{http}: / /$ www.bibl.plock.pl/index.php?ile=20 [dostęp 18.07.07].

${ }^{16} \mathrm{http}: / /$ www.ksiaznicapodlaska.pl/site/html/bp.html [dostęp 18.07.07].

${ }^{17} \mathrm{http}$ ///biblioteka.awf.krakow.pl/ [dostęp ze strony głównej Biblioteki-Wydawnictwa Biblioteki-Biuletyn Informacyjny 18.07.07].

${ }^{18} \mathrm{http}$ ://www.bn.org.pl/index.php?id=5\&czasop=2 [dostęp 18.07.07]. 
i naukowych z uwzględnieniem bibliotekarstwa, historii książki i czytelnictwa. Czasopismo o charakterze ogólnopolskim.

Dostrzegacz Biblioteczny: pismo informacyjne Wojewódzkiej Biblioteki Publicznej w Lublinie ${ }^{19}$ (ISSN 1732-4823) - kwartalnik wydawany od 1996 r. (od 2002 r. ma 2 wersje: drukowaną i elektroniczna) przez Wojewódzką Bibliotekę Publiczną im. H. Łopacińskiego w Lublinie. Pełny dostęp do tekstów artykułów możliwy jest $\mathrm{w}$ formacie pdf od nr $12002 \mathrm{r}$. Pismo zawiera informacje o sprawach bieżących bibliotek województwa lubelskiego. Czasopismo ma charakter regionalny.

Expres $\boldsymbol{Z G} \boldsymbol{S B} \boldsymbol{P}^{20}$ jest wydawany nieregularnie od 2002 r. przez Biuro Zarządu SBP. Zawiera informacje o bieżących sprawach dotyczących SBP, projekty planów wydawniczych, programy posiedzeń, uchwały. Czasopismo przeznaczone do użytku wewnętrznego, ale o zasięgu ogólnopolskim. Pełny dostep do tekstów jest $\mathrm{w}$ formacie pdf.

Fides: biuletyn bibliotek kościelnych ${ }^{21}$ (ISSN 1426-3777) - półrocznik wydawany od 1995 r. przez Federację Bibliotek Kościelnych FIDES w Krakowie. Pełny dostęp do artykułów możliwy jest przez Księgozbiór Wirtualny Federacji Bibliotek Kościelnych FIDES w formacie djvu od 2003 r. Czasopismo zajmuje się problemami bibliotek kościelnych w Polsce. Publikowane są w nim dokumenty i sprawozdania dotyczące działalności Federacji. Szczególną uwagę zwraca na zagadnienia związane m.in. z unowocześnieniem warsztatu pracy bibliotekarzy oraz wymianą doświadczeń między bibliotekami wszelkich typów. Czasopismo o charakterze ogólnopolskim.

Polish Libraries Today 22 (ISSN 0867-6976) wydawany jest nieregularnie od 1987 r. (od 2001 r. w wersji elektronicznej) przez Bibliotekę Narodowa. Artykuły są dostępne na stronach WWW w formacie pdf od nr 5/2001 r. do nr 6/2005 r. Pismo jest adresowane do zagranicznych środowisk bibliotekarskich. Zawiera artykuły, recenzje obejmujące zagadnienia informacji naukowej i czytelnictwa.

Poradnik Bibliograficzno-Metodyczny ${ }^{23}$ (ISSN 0238-9142) - kwartalnik wydawany od 1989 r. przez Wojewódzką Bibliotekę Publiczną i Centrum Animacji Kultury w Poznaniu. Poszczególne artykuły są dostępne w formacie doc od nr 1/2003 do numeru bieżącego. Kwartalnik zawiera zestawienia bibliograficzne, aktualne wydarzenia kulturalne, literackie i społeczne. Jest wydawnictwem regionalnym.

Rocznik Biblioteki Narodowej24 (ISSN 0083-7261) jest wydawany od 1965 r. przez Bibliotekę Narodową. Artykuły są dostępne na stronach WWW w formacie pdf od 2001 do numeru bieżącego. Pismo zawiera teksty o szeroko pojętej nauce o książce, rozprawy, artykuły, recenzje, opracowania z zakresu księgo-

${ }^{19} \mathrm{http}$ //hieronim.wbp.lublin.pl/wbp/b/onas/dostrzegacz.htm [dostęp 18.07.07].

${ }^{20} \mathrm{http}: / / w w w . e b i b . i n f o /[$ dostęp 18.07.07].

${ }^{21} \mathrm{http}$ ://digital.fides.org.pl/dlibra/publication?id=30\& from $=\&$ from $=$ metadatasearch $\&$ dirids $=1 \&$ tab $=1$ [dostęp 18.07.07].

${ }^{22} \mathrm{http} / / /$ www.bn.org.pl/index.php?id=5\&czasop=4\&elektr [dostęp 18.07.07].

${ }^{23} \mathrm{http}: / / \mathrm{www} . w b p . p o z n a n . p l /$ strony/2/p/801.php [dostęp 18.07.07].

${ }^{24} \mathrm{http}$ ://www.bn.org.pl/index.php?id=5\&czasop=1 [dostęp 18.07.07]. 
znawstwa, czytelnictwa, edytorstwa, tematyka polonijna. Tytuł jest wydawnictwem ogólnopolskim.

Wydawanie tych czasopism jest wspierane przez uczelnie i biblioteki. Jedynie tytuły wydawane przez Bibliotekę Narodową są wspomagane od 2002 r. przez Krajowy Depozyt Papierów Wartościowych. Wersje elektroniczne udostępniane są bezpłatnie na stronach WWW i pojawiają się równolegle $\mathrm{z}$ wersją drukowaną. Jedynie Fides oraz Biblioteka zamieszczają numery archiwalne na stronach bibliotek cyfrowych.

Czasopisma te są najczęściej redagowane przez kilkuosobowe zespoły pracowników bibliotek wydających dane tytuły. Autorami są nie tylko bibliotekarze, ale też osoby ze środowiska naukowego.

Elektroniczne publikowanie wcale nie oznacza spadku nakładu czasopisma, ani utraty czytelników. Wręcz przeciwnie, ze wszystkich tu opisywanych czasopism, żadne nie zmniejszyło nakładu. Bibliotheca Nostra nawet zwiększyła nakład wersji drukowanej.

W zasadzie połowa czasopism mających mutacje w formie elektronicznej, to czasopisma o tematyce lokalno-regionalnej. Można tu śmiało powiedzieć, że wydawcy traktują wersje elektroniczne jako formę reklamy.

Spośród pięciu pełnotekstowych czasopism elektronicznych jedynie $E B I B$ pretenduje do czasopisma elektronicznego $\mathrm{z}$ prawdziwego zdarzenia $\mathrm{z}$ całym zapleczem serwisu. Jest rozbudowanym źródłem informacji, w którego skład wchodzi biuletyn i serwis. Czasopisma Warsztaty Bibliotekarskie, Bibliotekarz Warmińsko-Mazurski oraz Biuletyn Informacyjny BG AE w Krakowie mają schemat organizacji strony w postaci dwukolumnowej tabeli, są efektywnie zagospodarowane. Odbiór wizualny tych czasopism jest dobry. e-Kurier $N B$ być może w ostateczności przybierze kształt typowego czasopisma elektronicznego; tymczasem komfort czytania wydawnictwa jest niski, bowiem wiadomości czyta się jednym ciagiem, brak aktywnych odnośników.

Nie można jednoznacznie odpowiedzieć na postawione we wstępie pytania: Dlaczego w dobie powszechnego Internetu tak mało czasopism z zakresu bibliotekoznawstwa widocznych jest w sieci? Posiadanie aktualnej i rzetelnej wiedzy jest jak najbardziej pożądane. Zainteresowanie środowiska czasopismami i literaturą zawodową jest dyskusyjne. A zatem przeszkodą są względy finansowe? Nie jest chyba problemem brak środków technicznych umożliwiających realizację projektów digitalizacji. Większość tych czasopism (tylko drukowanych lub tych, które umieszczają spisy treści na stronach WWW) wydawana jest przez ośrodki akademickie i biblioteki, które mają swoje strony domowe w sieci. Koszt utrzymania, opracowania i rozpowszechniania tych czasopism jest względnie niski w stosunku do wydawania ich drukiem.

A może przyczyn należy szukać w naturze naszej mentalności? Wydawcy czasopism z dziedziny bibliotekarstwa metody cyfrowe traktują jako wsparcie tradycyjnych metod publikacji. Chyba do takiej sytuacji przyczynia się samo środowisko. Artykuły opublikowane w wersji elektronicznej są uważane za mniej wiarygodne niż drukowane. Czasopisma elektroniczne będą odgrywać coraz większą 
rolę. Warto, więc zadbać o to, aby czasopisma te służyły jako panel wymiany myśli, dyskusji, rozwoju zawodowego, stanowiły fachowe wsparcie.

Możliwość przejrzenia elektronicznej wersji przed ukazaniem się tytułu w postaci drukowanej, szybki i komfortowy dostęp do informacji, możliwość przeglądania archiwów czy przechowywanie wybranych artykułów w folderach na własnym komputerze to zalety czasopism elektronicznych. Podstawowym elementem odróżniającym formę tradycyjną od elektronicznej: publikacja elektroniczna umożliwia - jeśli jest poprawnie skonstruowana - prostą i skuteczną nawigację w tekście. Daje to nam możliwość szybkiego dotarcia do innych prac interesujących nas autorów i informacji. A informacje w formie elektronicznej są praktycznie dostępne przez całą dobę bez względu na granice i odległości geograficzne.

Czasopismo w wersji drukowanej ze względu na swoją ograniczoną objętość nie jest w stanie zapewnić każdemu autorowi zaprezentowania w nim swojej pracy. Takie oczekiwania mogłyby spełnić czasopisma elektroniczne. Ze względu na możliwość ciąłej aktualizacji i poszerzania objętości są w stanie publikować znacznie więcej artykułów niż wydawnictwa tradycyjne. Czasopismo elektroniczne pozwala także na skrócenie czasu dystrybucji artykułu, możliwość natychmiastowego ustosunkowania się do prezentowanych treści, na łatwiejszy kontakt wydawcy z czytelnikiem i wymianę doświadczeń. Nie przeceniając wartości globalnej sieci można stwierdzić, że pojawienie się nowych tytułów na stronach WWW to tylko kwestia czasu. 